\title{
12 Aspiring and Becoming STEM Teachers in Hong Kong
}

\author{
A Gender Perspective
}

\author{
Hei-hang Hayes Tang, Derek Wai Sun Chun, Iris Chi \\ Yan Leung and Thomas Siu Ho Yau
}

Global low participation of women in Science, Technology, Engineering and Mathematics (STEM) education, as well as STEM-related jobs and professions, has drawn the attention of schools, educators, and policy makers. Reducing gender inequality in STEM may bring better equality and equity for world development (European Institute for Gender Equality, 2017). In Hong Kong, STEM education has become particularly timely since 2016 when the government launched policy initiatives which substantially impacted STEM education practices. Professional teachers have become crucial agents for inspiring students to build their aspirations for STEM-related occupations and professions (Margot \& Kettler, 2019). Therefore, in this chapter we consider how pre-service STEM teachers develop aspirations and capacity in women students to create a more gender equitable future in STEM disciplines and professions.

Sen's (1999) notion of the capability approach will be used as a conceptual framework for analyzing the collected data (Boni \& Walker, 2016). Although the capability approach has been utilized widely in elaborating on different gender and education issues, this study could be seen as a beneficial attempt to illustrate STEM gender-equity phenomenon. It also offers an insightful gender perspective on how STEM teachers-to-be perceived their teaching aspirations and constructed STEM teacher identities in Hong Kong. By using the methods of educational ethnography and qualitative interviewing, this chapter reports findings based on life stories (as cross-case studies) of eight pre-service women teachers majoring in STEM-related programs at the largest teacher training university in Hong Kong. We conduct iterative dialogues between the casestudy students and the researchers through autobiographical writings, feedback, and interviews. Educational autobiography involves critical reflection on one's learning experiences, actions, and aspirations (Franzosa, 1992; Powell, Zehm \& Garcia, 1996; Charissi, 2020). It is an ongoing reflective journey, which emphasizes critical inquiry and questioning about one's own behaviors, beliefs, and values. Empirical findings and analysis from this study will add contextual knowledge to the broader literature of science education, teacher identity, and teacher development, especially by understanding teacher identity as a process (Avraamidou, 2014). This chapter will also inform policy recommendations

DOI: $10.4324 / 9781003053217-3$ 
about teacher education, career and life planning education, and the role of STEM teachers in pursuing gender justice (Molyneux \& Razavi, 2002) in different education systems across the world.

\section{STEM, Education, and Gender in Hong Kong}

STEM has gained increasing attention from countries over the past decade (Sanders, 2009). In Hong Kong, in response to the ever changing economic, scientific, and technological development, STEM education was first proposed by the Hong Kong Special Administrative Region's former Chief Executive, Leung Chun-ying, in the 2015 Policy Address and furthered in the 2016 Policy Address. STEM education acts as a key emphasis in the ongoing renewal of the school curriculum that is essential for students' life-long learning and whole-person development. With the implementation of STEM education in schools, apart from cultivating students' interest and developing a solid knowledge base in science, technology, and mathematics, Hong Kong also aims

to strengthen students' ability to integrate and apply knowledge and skills across different STEM disciplines, and to nurture their creativity, collaboration and problem solving skills, as well as to foster their innovation and entrepreneurial spirit as required in the 21st century. (Education Bureau, 2016, p. 1)

Given the strategy proposed in the 2015 and 2016 policy addresses, the Hong Kong government adopted a holistic and integrated approach to implement STEM education, including 1) renewing the curricula of the science, technology, and mathematics education as key learning areas; 2) enriching learning activities for students; 3) providing learning and teaching resources; 4) enhancing the professional development of schools and teachers; 5) strengthening partnerships with community key stakeholders; and 6) conducting reviews and disseminating good practices (Education Bureau, 2016, p. 2). In view of this latest development in STEM education, professionalism of STEM education is the priority, as based on the proposed policy agenda, which creates training programs and in-service programs to expand beneficiaries to a larger group of stakeholders.

Generally, Hong Kong maintains an excellent performance record on different international assessments. TIMSS (Trends in International Mathematics and Science Study) and PISA (Programme for International Assessment) have indicated that the education systems for science and mathematics in East Asian countries, like Hong Kong, are among the top ten in the world (Mullis et al., 2016). Hong Kong is promoting STEM education as a crucial step towards fostering an innovative mindset among students (Education Bureau, 2016). With strong primary and secondary school preparation, as evidenced by TIMSS and PISA, there has been a steady increase in the number of 
students enrolling in STEM programs at the university level over the last decade. There were 26,525 students studying STEM-related subjects ${ }^{1}$ at local universities funded by the University Grant Committee in 2006/2007, 27,323 in $2011 / 2012,35,925$ in 2016/2017, and 36,971 in 2018/2019, respectively (Census and Statistics Department, 2019a). However, gender imbalance has been prominent. Among undergraduate programs in the sciences, there were approximately $36 \%$ women and $63 \%$ men in $2006 / 2007$. In $2018 / 2019$, the gender imbalance persisted with women making up approximately $39 \%$ of the student population of STEM-related majors. For engineering and technology disciplines, $31 \%$ were women in 2006/2007 and the figure dropped to $29 \%$ in 2018/2019 (Census and Statistics Department, 2019b). However, there were more women university students than their men counterparts in the majors of Dentistry (64.3\%) and Medicine (51.4\%) (Women's Commission, 2019).

In Hong Kong, the demand for talent with STEM-related skills has been rising in response to global changes. In 2008, 103,107 people $(2.94 \%$ of the total workforce) worked in information and communication technology. This figure had increased to 129,641 in 2017 , which equaled $3.39 \%$ of the total workforce (Census and Statistics Department, 2019a; 2019b). Gender difference remains a serious issue in the STEM workforce. In the information and communications industry, men outnumber women constantly. Estimates suggest that there were 74,000 men and 35,400 women working in the information and communications industry in 2008, and 92,700 men and 41,800 women in the industry in 2018 (Census and Statistics Department, 2019b).

Like other post-industrial countries, including the United States, Hong Kong has experienced gender imbalance in STEM-related work (Beede et al., 2011). The gender imbalance of STEM-related study and work in Hong Kong is driven by different factors. Yeung and Liao's study (2016) concluded that junior secondary students studying STEM-related subjects were affected by their childhood experience and exposure to STEM, their self-perceived ability, selfinterest, and aspirations. These experiences were shaped by social structural factors stemming mainly from school. Gender stereotypical beliefs on the part of students and teachers significantly affect girls' intention to study STEM subjects. According to another, larger mixed method study (Chan \& Cheung, 2018), which surveyed 2,807 International Standard Classification of Education (ISCED) level 3 students in Hong Kong, there are gender differences in taking STEM-related electives in The Hong Kong Diploma of Secondary Education (HKDSE). Compared with men, women students are 28\% less likely to take at least one STEM elective and $41 \%$ less likely to take extended/advanced mathematics modules in the HKDSE curriculum. The gender differences in taking physics and information and communication technology (ICT) electives are even larger. Women are approximately $52 \%$ and $72 \%$ less likely than men students to take these subjects, respectively. Even when women have taken STEM-related electives in HKDSE, they are less likely to consider STEM majors in higher education and when pursuing STEM-related careers. Despite some women students investing more resources and time in STEM electives 
than men, they still hold more negative perceptions of, and are less interested in, STEM learning domains (Chan \& Cheung, 2018).

Students' subject perception (self-efficacy, interests, and perceived value), preference on job characteristics, and stereotypical beliefs in STEM are important in explaining women's choice and dropout rate at different stages of learning. Low self-efficacy in STEM subjects undermines their persistence in STEM studies or careers (Simon, Aulls, Dedic, Hubbard \& Hall, 2015). Compared with men students, women in Hong Kong report a more positive perception of the language/humanities domain (Chan \& Cheung, 2018). In addition, women students typically hold stronger gender stereotypical beliefs about STEM, such as the perception that boys are better than girls in learning science or the idea that girls are more suitable to studying language and humanities.

Cultural norms and concern surrounding university entrance also exerts an influence on students' subject choices. In fact, most secondary schools in Hong Kong with good academic performance numbers prefer science to arts streams and place a higher regard on STEM subjects. Prestigious majors in Hong Kong's universities, such as medicine, dentistry, and global business administration, welcome talented graduates from the science stream. Those high achieving students, including women students, would consequently choose science subjects due to status concerns and for strategic reasons. Moreover, the newly established Hong Kong Academy of Sciences, which aims at boosting the science, technology, and innovation systems in the region and raising the profile of Hong Kong as a center of scientific excellence, recommends greater emphasis on advanced mathematics and extols the future career prospects of studying STEM (The Hong Kong Academy of Sciences, 2017).

As a result of prioritizing or favoring STEM education, there is clear stratification between elite students who tend to study the science stream and their non-elite peers in the arts stream. In 2019, more than half of the HKDSE Examination candidates did not take any STEM elective subjects ${ }^{2}$ whereas the enrolment in advanced mathematics declined remarkably from over $22 \%$ in 2011-2012 to approximately 14\% in 2018-2019 (Legislative Council Secretariat, 2020). Moreover, the narrow job prospects for STEM graduates because of the underdeveloped innovation system of Hong Kong (Sharif \& Tang, 2014; Lo \& Tang, 2020; Tang, 2020; Tang \& Chau, 2020) hinders the majority of non-elite students in their aspiration for higher education and careers in STEM-related fields.

In the next section, we will discuss the socio-cultural construction of STEM teacher identity. We will especially consider how teachers can challenge stereotypes and help students question assumptions that lead them away from aspirations for the STEM fields. Teachers are seen as important agents for shifting gender stereotyping in STEM and related future careers among students and for pursuing gender justice during the schooling processes. 


\section{Construction of STEM Teacher Identity}

The conceptual construct of teacher identity is useful for examining teacher learning and development of pre-service STEM teacher identity, particularly in understanding teacher identity as a process (Avraamidou, 2014). According to Trent (2010), teacher identity is an iterative process of construction encompassing the dynamics of creation and recreation. This echoes the view by Britzman (2003) that learning to teach is "the process of becoming: a time of formation and transformation, of scrutiny into what one is doing, and who one can become" (p. 31). She claims that becoming a teacher is a struggle for voice. The interplay and negotiation of three dimensions of voice, namely, biography, emotions, and institutional structure, which contribute to teacher identity formation. Biography is the experiences of a person's life and of their journey of schooling. Emotions are about the personal, intimate, and internal aspects of teacher identity and how inconsistencies, uncertainties, and something kept silent contribute to becoming a teacher. Institutional structures represent forces that legitimize and exert influence over subjectivities and practices within teaching (Britzman, 2003; Huang, et al., 2019).

Wenger (1998) considers identity as the process of engagement, imagination, and alignment. Teachers can learn through engaging in different communities of practice, referring to "groups of people who share a concern, a set of problems, or a passion about a topic, and who deepen their knowledge and expertise in this area by interacting on an ongoing basis" (Wenger et al., 2002, p. 4). Teacher identity is formed by different components including subject knowledge, shared values, self-efficacy, a sense of membership, beliefs, and so on (Collopy, 2003; Drake, et al., 2001; Wenger, 1998). Those shared attributes enable the differentiation of one teacher group from another (Sachs, 2001).

In the existing literature, most previous research focused on the identity of science teachers, while less is known about STEM teachers. Only in recent years has there been an emerging field of research investigating the topic of STEM teacher identity. For example, Horvath, et al. (2018) found that teacher identity and the satisfaction of student teaching experiences predict pre-service STEM teachers planned and actual entry into the teaching profession. Teacher identity also mediates the relationship between perceived satisfaction and outcomes of student teaching. Additionally, El Nagdi, et al. (2018) interviewed eight STEM teachers to better understand the unique nature of STEM teacher identity and found that almost all teachers interviewed saw their identity as a developing/ emerging identity. Social and personal factors continuously impact teachers' views of themselves and their roles. Nevertheless, collaboration, flexibility, awareness of students' needs, and advocating equity and inclusion were identified as pivotal characteristics of STEM teachers.

While embracing the broader perspective that STEM is more comprehensive than individual science subjects, the STEM teachers in the study still cling to their individual identities as teachers of stand-alone subjects. El Nagdi and Roehrig (2020)'s follow-up study demonstrated professional growth of STEM 
teachers that had a progressive mindset and student-centered classroom practices. Sampled teachers were able to consider themselves as moving towards to an established STEM teacher identity, which was initially seen as a dialogical, dynamic, and evolving process that results from the interaction of personal and professional traits within new educational experiences. Another study tried to design an initial framework for STEM teacher identity in terms of four attributes that teachers develop across places and time: behaviors, practices, beliefs, and pedagogical knowledge (Adams, 2020). The framework outcomes were: motivation and engagement with STEM; achievement in STEM and pursuit of STEM interests and careers (Adams, 2020).

To summarize, it is understood that STEM teacher identity is an important concept for making sense of the changes and continuities of issues related to teacher education, gender, and STEM. Compared with the well-researched area of science teacher identity, identity of STEM teachers is more complex and multifaceted and it is emerging as a research field alongside the development of STEM and changing gender relations.

\section{Capability Approach in Education}

This study adopts the capability approach (Sen, 1999; Boni \& Walker, 2016) as the conceptual framework. The capability approach is a normative and theoretical framework for addressing human inequalities and enhancing individuals' well-being, human development, and justice. It claims that it is a moral obligation of a society to guarantee people's freedom to achieve wellbeing. Also, human capabilities are essential for individuals to pursue and attain well-being. Alongside "capabilities," the concept of "functionings" is central to the capabilities approach (Boni \& Walker, 2016). A functioning refers to "the various things a person may value doing or being" (Sen, 1999, p. 75). Capabilities, on the other hand, refer to the freedoms (opportunities, potentials) a person has in order to make reasoned and reflective choices about using the resources they have (material, educational opportunities, public policy, etc.) in realizing their valued functionings. Evaluation of a person's well-being focuses on this interplay between capabilities and functionings. Factors affecting the process by which capabilities are converted into functionings are referred to as "conversion factors" (Robeyns, 2003). There are three categories of "conversion factors," namely, personal conversion factors, social conversion factors, and environmental conversion factors (Robeyns, 2017). Resources, such as the availability of various sorts of materials or any other personal, social, or environmental goods and influences, impact capability formation and conversion factors (Walker \& Loots, 2018). Regarding the focus of this chapter, the social conversion factor of education (such as a teacher preparation program for pre-service STEM teachers) is emphasized as the central point of analysis. This is because teacher education for STEM teaching and learning transforms the resources (e.g. new knowledge of STEM, state of the art technological development, and pedagogical knowledge and 
skills of teaching STEM subjects) and capabilities of women student teachers into their functionings. They then value the role of women STEM teachers and aspire to become a STEM teacher in the future and start to develop their teacher identity.

We use the capabilities approach as the conceptual framework in this chapter to inform the research questions, guide data collection and coding, interpret the qualitative data and develop implications for policy and practice. The approach is useful in evaluating policies and practices, especially those in education, and for developing agency, fostering aspirations, and achieving well-being of women teachers and students (DeJaeghere, 2018). Based on the conceptualization of capabilities, the framework is applied to examine the teacher identity formation process of Hong Kong's women pre-service teachers by addressing three research questions: (1) What are the factors that shaped the aspiration of women students in Hong Kong for studying an education degree in STEM-related education? (2) What are their lived experiences of studying the degree as a process of constructing their teacher identity and becoming a STEM teacher? (3) Does gender make a difference in the process of aspiring to become and becoming a STEM teacher? Why and how?

The capability approach has enormous potential for addressing feminist concerns and questions related to health, voting power, political power, domestic violence, education and women's social status (Kameshwara \& Shukla, 2017). Robeyns (2003) considered capabilities as real opportunities and selected a list of relevant capabilities. A gender inequality assessment was designed following a four-step process: unconstrained brainstorming, testing a drafted list of capabilities against available literature, engaging with other lists of capabilities, and debating the list with other people. Education and knowledge were among the list of capabilities Robeyns (2003) highlighted education and knowledge she thought imperative, suggesting that capability analysis of educational equality should investigate the hurdles faced by girls in educational achievements, such as sexist behavior, sexual harassment, gender differences in expectations, and encouragement against a men-dominated class atmosphere. These dimensions and concerns of the capabilities framework will guide the data coding and analysis which will be reported after the methodology section.

\section{Methodology}

This study uses educational autobiography (Franzosa, 1992; Powell, et al., 1996; Medina, 2016) and qualitative interviewing as research methods to guide the processes of data collection. Educational autobiography highlights an ongoing process which emphasizes critical inquiry and questioning about one's perceptions, beliefs, values, and behaviors. Through critical self-examination of an individual's beliefs, values, and practices, students undergo a transformation of their understanding about the particular issues of gender, STEM, capabilities, and teacher identity, and construct new knowledge through self-discovery and reflection of those issues (Ukpokodu, 2003). The reflective journey through 
an educational autobiography helps participants self-examine ways they respond to cognitive dissonance and change (Gunn et al., 2013).

According to the Transformative Learning Theory by Mezirow (1997), transformation through critical reflection and discourse occurs when an environment is safe and comfortable. People's interpretation of experiences with gender, education, capabilities, and identities are shaped by unconscious assumptions, worldviews, biases, or even prejudices. Those assumptions affect our beliefs, selfefficacy, decision-making, and interactions with others (Childs, 2005). Hence, the research methods of educational autobiography and qualitative interviewing offer valuable tools for pre-service teachers to critically question their deep-rooted assumptions and worldviews, experience transformation of their self-awareness, and construct better-informed knowledge. Also, critical reflection can enable students to gain knowledge of self and others, and more importantly, to recognize connections to and differences from others (Gunn et al., 2013).

In this study, eight student teachers of different STEM-related subjects (ranging from Biology, Chemistry, Information and Communications Technology, and Physics to Mathematics) were purposefully selected at the largest teacher training university of Hong Kong for the research sample (Table 12.1). Before formal interviews were conducted, each research participant was asked to write a reflective essay in response to guiding questions informed by the capabilities approach. The researchers read through the reflective essays and developed specific questions for the interview guide afterwards. The individual, semi-structured interviews, conducted from March to May of 2020, lasted for 1 to 1.5 hours with the aid of the contextualized interview guide. Based on the research questions, the interviews covered dialogues about the following open-ended themes:

- Can you share your story of why you become a pre-service teacher at this university? Why did you choose this major?

- What is your understanding about the new field of "STEM"? How is it different from other subjects, including the traditional science subjects?

- To what extent would you relate your major with the field of "STEM"? How and why?

Table 12.1 Research Respondents Information

\begin{tabular}{lll}
\hline & Major (Bachelor of Education, specialization) & Year of study \\
\hline Respondent 1 & Mathematics & 5 \\
Respondent 2 & Mathematics & 1 \\
Respondent 3 & Information and Communication Technology & 3 \\
Respondent 4 & Mathematics & 5 \\
Respondent 5 & Science & 3 \\
Respondent 6 & General Studies & 4 \\
Respondent 7 & Information and Communication Technology & 2 \\
Respondent 8 & Information and Communication Technology & 3 \\
\hline
\end{tabular}


- Can you tell us more about your learning experiences? What makes you identify yourself as a pre-service "STEM teacher," or not?

- Can you tell us more about your teaching experiences, including teaching practicums and part-time teaching jobs? How do they help you to construct your "teacher identity"?

- Does gender make a difference in the processes of aspiring and becoming a STEM teacher? Why and How?

- What are the needs for professional training of STEM teachers and implications for teacher education?

- Do you have any comments about the development of Science Education and teacher training/education in Hong Kong?

Verbatim transcription was produced for all interviews. The transcripts were read and re-read for thematic coding (Gibbs, 2007) guided by the conceptual framework of the capabilities approach.

\section{Positionality}

As qualitative researchers, we acknowledge our own role as interpreters for understanding the interview guide, engaging in dialogue during the interview processes, coding the data, generating themes, and analyzing the codes and themes from the qualitative data. Our training, experiences, and curiosities might have influenced the path of investigation, quotes selection, and themes identification (Luttrell, 2010). By way of ensuring the trustworthiness of this study, we make our positionality as researchers transparent (Luttrell, 2010; Walther, et al., 2013) and enhance the inter-rater reliability by coding and analyzing the data together. We identify ourselves as education researchers with similar ethnic backgrounds (Chinese, native-born in Hong Kong). Four of us had post-graduate training as educational researchers with different expertise and we all have research experience in education and gender. Three of us have experience teaching undergraduates and offering professional development programs in education.

\section{Findings}

The iterative processes of thematic coding discovered four themes from the qualitative data of educational autobiography and follow-up interviews. They are (1) motivations for aspiring to become STEM teachers, (2) gender stereotyping and STEM performance, (3) gender and aspirations for teaching STEM, and (4) gender and STEM teacher identity.

\section{Motivations for Aspiring to Become STEM Teachers}

Data from this study reveal that women students in teacher pre-service programs in Hong Kong do not face educational inequalities in accessing opportunities or resources for STEM-related education. They saw the importance of 
advanced technology and rising demand for STEM-related education in the new century. The educational processes, as the key social conversion factors in this study, facilitate the development of their aspiration, as well as capabilities and functionings. The women STEM pre-service teachers in Hong Kong generally possess the freedom, opportunity, and potential to make reasoned and reflective choices about using the resources they have through the teacher training program at the education university in realizing their valued functionings, i.e., becoming a professional STEM teacher in the future. In response to the question of why they chose an education major related to STEM, a respondent shared:

It is for better equipping myself for the new demands of the era. Nowadays, digital and technology-enabled teaching has become increasingly important. As young professionals to be, we should proactively learn and understand the knowledge of this aspect. As for me, I have a science background. I have a comparative edge of science, and my university major is primary mathematics education. I think I have the capability to further my studies about STEM-related teacher professional development. (Respondent 1, BEd Maths (Primary), Year 5)

Another respondent echoed the similar perspective and aspiration, especially in view of the prevalent trend of technology-enabled teaching across subject curriculum and the cross-curricular skill of design thinking:

In the current context of education, technology is increasingly integrated with other subjects, such as General Studies and Mathematics. Integrating technology with these two subjects enables us to teach students how to stimulate their design thinking or other new thinking approaches. Further, it may help their learning in Science. (Respondent 2, BEd Maths (Primary), Year 1)

\section{Gender Stereotyping and STEM Performance}

Despite the availability of opportunities and resources for STEM education and teacher training, students in Hong Kong still hold subjectivities about gender disparities in science performance which can in turn affect their capabilities and functionings building. Participants had personal conversion factors of self-efficacy and competencies to pursue STEM subject knowledge. These factors, combined with students' capabilities of reframing the traditional stereotyping of gender and STEM, help to make sense of the varied perceptions and subjectivities among the participants in this research. Respondent 1 perceived that there are gender differences in confidence and self-efficacy in learning and achievement in STEM-related subjects: 
Indeed, there are some gender differences in terms of self-confidence. Some girls think that boys are good at math, while boys somehow show their confidence in math. Although the teacher teaches us in the same way and s/he would not say which students are good or who are bad, some female students always like to say "the boys in that class are really good at math." Also, male students are in general more confident and active in class. Perhaps that's why they have better learning. (Respondent 1, BEd Maths (Primary), Year 5)

Such gender biased perceptions of Hong Kong women students affect their everyday interactions and personal observations about gender differences and inequality. The performance in Mathematics and Science subjects are also varied. One respondent stated:

For me, I hope there is no gender inequality. However, in my observation, as I had minored in science and attended to some science classes, most of them are men. The class performance of the men was better and more active than women, men were more willing to express their ideas and share with the professor, while women might not be the same. That's what I have observed in science lessons. But, it's different in mathematics lessons: most of the women perform well in math as you may need to be circumspect about mathematics. Everyone has her/his own strengths. As for me, I am not good at mathematics like Algebra. (Respondent 1, BEd Maths (Primary), Year 5)

\section{Gender and Aspirations for Teaching STEM}

The social conversion factors concerning social norms about STEM and gender affect the capabilities-functionings conversion through teacher education for pre-service STEM teachers, particularly in terms of empowerment of women student teachers for their disciplinary, interdisciplinary, and pedagogical knowledge and skills. With regard to developing aspirations for becoming a STEM-related teacher in Hong Kong, gender appears to be a more multifaceted issue than common assumptions hold. It is due to the gendered division of labor within Hong Kong's occupational structure that school teaching is relatively a feminine job, especially at the primary level. In response to the question about whether gender may affect the aspiration of becoming a STEM teacher in Hong Kong, a pre-service primary school mathematics teacher shared an alternative view:

It is hard to say whether gender stereotyping would affect the aspiration of becoming a teacher or not, as there is no relationship between gender and this aspiration ... Why can't girls study science? Why can't men study liberal arts? This is all about your attitude and your own choices. Don't be influenced by the society! (Respondent 2, BEd Maths (Primary), Year 1) 
Another respondent who was studying science education for high schools admitted that it takes time to nurture a woman role model in the field of STEM education across Hong Kong communities because women's self-esteem and self-efficacy seem relatively lower than men in terms of STEM competency. The finding affirms the effect of personal conversion factors, which can be reworked by the emerging environmental factors of capabilities-functionings conversion, especially in view of the role model of women STEM teachers:

As a woman, I am confident as I have relevant knowledge about STEM. Gender does not affect my teaching. However, I've read the news about Hong Kong's lack of women in STEM, I have the same feeling that men are relatively better than women. For example, men can complete tasks about programming and debugging more efficiently, while women might not be that fast or clear. In fact, I agree with the statement to a certain extent. (Respondent 5, BEd Science, Year 3)

\section{Gender and STEM Teacher Identity}

Concerning the professional identity of STEM teachers, the personal conversion factors relating to gender image and self-efficacy become even more important when gender stereotyping and bias are perceived and embodied individually. Some people in Hong Kong have an image of the professional, "archetypal" STEM teacher as a man more than as a woman. A respondent shared this opinion in reply to the question about whether gender factor affects her perception concerning the professional identity of STEM teachers:

I am worried others may think that I don't have as much computer knowledge as men do and that I cannot handle teaching well. Such personal perception makes me feel bad. (Respondent 5, BEd Science, Year 3)

Another respondent revealed her subjectivities about gender image and educational leadership in the STEM fields:

Perhaps it's because of the traditional mindset I used to hold. I think men's logical thinking is better than that of women. As for promoting teachers to be school leaders, most of the successful cases are men. Therefore, it seems more preferable promoting a male teacher to a female colleague. Let's take chemistry as an example, it's better to have a male teacher. By comparing some of my chemistry teachers, male teacher's lessons are more down-toearth and catchier. Female teacher's lessons are rather wishy-washy. They deliver knowledge related to the subject, yet whether the knowledge is important or not, no one knows. Therefore, I think it would be better to have a male chemistry teacher. However, for the subject of biology, it involves different topics like organisms, plants and the environment. Thus, I think female teachers are alright. (Respondent 5, BEd Science, Year 3) 
However, another pre-service teacher envisioned that successful women STEM teachers should be established as the role model over time. The following interview data shows the significance of environmental conversion factors of women role models in the STEM fields amidst the global trend of new human capital demands in the STEM fields and the opportunities for greater gender justice:

So far, I have never seen a female teacher of ICT. Instead, female teachers are well-positioned in handling gender's issues in STEM teaching and learning, they will consider it from a female's point of view. (Respondent 7, BEd ICT, Year 2)

\section{Summary of the Research Findings in Light of the Capabilities Framework}

Results of this research show that capabilities-functionings conversion factors do not stand-alone but interact with one another in the identity formation processes of women pre-service STEM teachers in Hong Kong. It is the interaction of these factors that converts capabilities into functionings and well-being (Chiappero-Martinetti \& Sabadash, 2014). Social and personal conversion factors play a role in the educational and professional development processes in STEM teacher education of student teachers. The findings also show that the personal and social conversion factors can be reworked by emerging environmental factors, especially in view of the role model of women STEM teachers amidst the global trend of talent shortages in the fields and the opportunities for greater gender justice.

Table 12.2 presents the summary of conversion factors from capabilities into functionings among women STEM pre-service teachers in Hong Kong. Based on the empirical findings, we found that the personal conversion factors can be categorized into (1) self-efficacy, referring to belief in one's own competencies and capabilities to pursue STEM as teachers; (2) STEM subject knowledge (referring to academic knowledge and interdisciplinary knowledge) and skills for pedagogical practices in STEM class teaching and activities; and (3) perception on gender stereotyping, i.e., the capabilities of individual women pre-service STEM teachers in reframing the traditional stereotyping of gender and STEM.

As mentioned earlier, teacher education for pre-service STEM teachers is the central social conversion factor for this study, as it directly contributes to the empowerment of women STEM student teachers for their disciplinary, interdisciplinary, and pedagogical knowledge and skills. STEM teacher education helps convert their capabilities into functionings, valuing their aspirations of becoming a STEM teacher, and realizing their valued functionings. The effect and outcome of STEM teacher education are contextualized against other social conversion factors, which include social norms concerning socialization of family, school, and peers regarding STEM and gender. 
Table 12.2 Summary of Conversion Factors From Capabilities into Functionings among Women STEM Pre-service Teachers in Hong Kong

Personal conversion factors

Self-efficacy

STEM subject knowledge

Perception of gender stereotyping

Social conversion factors

Teacher education for pre-service STEM teachers

Social norms

Environmental conversion factors

New human capital demand in the STEM fields and opportunities for greater gender justice

Global trend of STEM-led development and changing civic life in the digital age
Belief in own competencies and capabilities to pursue STEM as teachers

Academic knowledge and interdisciplinary knowledge and skills for pedagogical practices in STEM class teaching and activities

The capabilities of reframing the traditional stereotyping of gender and STEM

Empowerment of student teachers of STEM for their disciplinary, interdisciplinary, and pedagogical knowledge and skills

Socialization of family, school, and peers about STEM and gender

Importance of women role models in the STEM fields

Cultivation of digital literacy and career and life planning for STEM-related future career/ entrepreneurship and youth engagement

In a broader sense, environmental conversion factors interact with personal and social conversion factors in affecting the career aspiration and identity formation processes of student teachers of STEM teacher education. The new demand for human capital in the STEM fields gives rise to the possibilities of establishing women role models in the STEM fields, be they in the teaching profession or in other sectors and industries. These role models will play a positive part in the facilitation of capabilities-functionings conversion and in enhancing the opportunities for greater gender justice. Meanwhile, the global trend of STEM-led development and changing civic life in the digital age call for the cultivation of digital literacy in schoolchildren and of career and life planning for a STEM-related future and youth engagement.

\section{Discussion}

The key findings of this study show that women pre-service teachers in Hong Kong do not have less access than their men counterparts to the freedoms, educational opportunities, or human potential to make reasoned and reflective choices about the resources offered by educational policies and schooling practices to build capabilities for becoming STEM-related professional teachers in the future. They also have the functionings to value the professional engagement of STEM education, becoming role models of women STEM 
educators and deconstructing the existing gender stereotypes about STEM teaching and learning. To a certain extent, education in Hong Kong offers positive conversion factors for changing women students' capabilities into functionings, and realizing their valued functionings.

The main findings echo the literature of Hong Kong education and gender which reports that women students are not in relatively disadvantaged positions for the development of their capabilities and functioning. For example, previous research found that there are no gender differences in intrinsic motivation for education among university students in Hong Kong (Yau et al., 2012) and school girls reported higher levels of life satisfaction and spiritual health than their school boy peers (Yuen, 2015). In fact, the percentage of women university students are higher than men in the majors of Dentistry $(64.3 \%)$ and Medicine $(51.4 \%)$, despite the gender imbalance in Science (38.7\%), and Engineering and Technology (29.4\%) (Women's Commission, 2019). There was an increase in gender equity in terms of the visual and textual representation of women in the primary school English-language textbooks. However, some stereotyped images of the both sexes still persist such that women are portrayed in a more limited range of social roles which reinforce the 'male-first' phenomenon (Lee, 2014).

\section{Implications and Conclusion}

Based on the empirical analysis of this study, we demonstrate the potential of the capabilities approach to serve as a framework for addressing gender inequalities and enhancing students' well-being, human development, and justice within STEM fields and within the Hong Kong education context. Overall, our women pre-service teacher respondents provide a perception that gender stereotypes are concealed in STEM professions, coming from their first-person perspective. Although gender inequalities within STEM education and the local education system are not noticeable, gender stereotyping in STEM fields still exists in society, schools, and the mental outlook of individual women pre-service STEM teachers in Hong Kong. Empirical findings of this study show how stereotypes about women in STEM can sometimes be perpetuated by everyday interactions in the classroom, especially when STEM teachers are not conscious of the fact that stereotypes are internalized and are continuing to make their way into classrooms and schools. Therefore, Hong Kong schools are urged to initiate more diverse types of STEM programs because it can develop capabilities for women's aspirations and fascination for STEM and motivate their participation in the STEM taskforce (Cannady et al., 2017). One of the local popular programs Girls Go Tech (GGT) School Programme, which is a year-long, schoolbased program launched in 2015, aims to encourage women secondary school students from deprived backgrounds to pursue traditionally maledominated, STEM-related subjects to maximize their future career options (The Women's Foundation, 2015). Lam (2018) reported students successfully 
develop different employability skills to help achieve their future academic and career goals in STEM fields after participating in the program. When gendered stereotypes regarding STEM success threaten the career choices of women, they can also have damaging consequences on women's STEM selfefficacy and career motivation (Cundiff et al., 2013; Mascret \& Cury, 2015) and can negatively affect future career aspirations. To improve the effect of women's stereotyping on STEM aspirations, their expected feelings in STEM and exploration of STEM identity deserve more attention in our professional training programs and career and life planning education (Schuster \& Martiny, 2017). The explicit perception of a STEM identity can nurture a better formulation of STEM teacher identity and aspiration in STEM professionals (Seyranian et al., 2018).

As for the case of Hong Kong, it is even more timely to develop role models of women as active STEM educators and practitioners and democratize the worldview of STEM education and teacher identity. The education system is morally obligated to guarantee students of both genders the opportunity to achieve well-being. In the century of accelerating technological advancement, human capabilities for digital literacy as well as STEM literacy are of special importance to pursue and attain an improved wellbeing for our young women in STEM development. Achieving STEM aspirations through STEM teachers can be treated as equipping capabilities to accomplish functionings to overcome gender inequities in the STEM fields. Empirical analysis of this chapter recommends future research and policy directions for designing and implementing gender-equity intervention with a view to addressing the influences of stereotypes that threaten STEM teacher aspirations. Among various interventions, teacher education programs and professional development can help pre-service and practicing teachers to challenge their own assumptions and stereotypes so that they can, in turn, empower the younger generations to tackle the "gender-equality paradox" in Hong Kong throughout their careers as teachers of STEMrelated subjects (Breda, et al., 2020; Buck, et al., 2020). University faculties or schools of education can take on the intellectual leadership required by initiating open platforms and developing professional learning communities for discussing and co-developing gender-just institutional policies and practices for STEM education.

\section{Notes}

1 STEM-related programs include biological science, physical science, mathematical science, computer science and information technology, engineering and technology, architectural studies and town planning (Hong Kong Government of SAR, 2018. https://www.info.gov.hk/gia/general/201811/28/P2018112800583.htm

2 Mathematics is one of the four core subjects, whereas Biology, Chemistry, Physics, Combined Science, Integrated Science, Mathematics "module one" (M1) and Mathematics "module two" (M2) are STEM-related elective subjects. 


\section{References}

Adams, J. D. (2020). Designing frameworks for authentic equity in science teaching and learning: Informal learning environments and teacher education for STEM. Asia-Pacific Science Education, 1-24. https://doi.org/10.1163/23641177-BJA10016

Avraamidou, L. (2014). Studying science teacher identity: Current insights and future research directions. Studies in Science Education, 50(2), 145-179.

Beede, D., Julian, T., Langdon, D., McKittrick, G., Khan, B. and Doms, M. (2011). Women in STEM: A gender gap to innovation. Economics and Statistics Administration Issue Brief No. 04-11. https://papers.ssrn.com/sol3/papers.cfm?abstract_id=1964782

Boni, A., \& Walker, M. (2016). Global human development: Theoretical and empirical insights for social change. Routledge.

Bottia, M., Stearns, E., Mickelson, R., Moller, S., \& Valentino, L. (2015). Growing the roots of STEM majors: Female math and science high school faculty and the participation of students in STEM. Economics of Education Review, 45, 14-27. https://doi. org/10.1016/j.econedurev.2015.01.002

Breda, T., Jouini, E., Napp, G., \& Thebault, G. (2020). Gender stereotypes can explain the gender-equality paradox. Proceedings of the National Academy of Sciences, 117(49), 31063-31069.

Britzman, D. P. (2003). Practice makes practice: A critical study of learning to teach. State University of New York Press.

Buck, G. A., Cross-Francis, D, \& Wilkins-Yel, K. G. (2020). Research on gender equity in STEM education. In C. C. Johnson, M. J. Mohr-Schroeder, \& T. J. Moore (Eds.), Handbook of research on STEM education (pp. 289-299). Routledge.

Carrier, S. J., Whitehead, A. N., Walkowiak, T. A., Luginbuhl, S. C. and Thomson, M. M. (2017). The development of elementary teacher identities as teachers of science. International Fournal of Science Education, 39(13), 1733-1754.

Census and Statistics Department. (2019a). Hong Kong as an information society. Hong Kong Census and Statistics Department.

Census and Statistics Department. (2019b). Women and men in Hong Kong - Key statistics. Hong Kong Census and Statistics Department.

Chan, N., \& Rosenthal, H. (2014). Working memory moderates stereotype threat effects for adolescents in Hong Kong. Revue internationale de psychologie sociale, 27(3-4), $103-118$.

Chan, A. K. W., \& Cheung, A. K. L. (2018). Gender differences in choosing STEM subjects at secondary school and university in Hong Kong. The Women's Foundation.

Cannady, M., Moore, D., Votruba-Drzal, E.et al. (2017). How personal, behavioral, and environmental factors predict working in STEMM vs non-STEMM middle-skill careers. International fournal of STEM Education, 4(22). https://stemeducationjournal. springeropen.com/articles/10.1186/s40594-017-0079-y

Chan, K. Y. C., Yeung, N. C. J., Kutnick, P. and Chan, R. Y. Y. (2019). Students' perceptions of engineers: Dimensionality and influences on career aspiration in engineering . International Fournal of Technology and Design Education, 29, 421-439.

Charissi, A. (2020). The educational autobiography as a critical reflection tool towards personal and professional development of pre-service early years practitioners. European Fournal of Education Studies, 7(2).

Chiappero-Martinetti, E., \& Sabadash, A. (2014). Integrating human capital and human capabilities in understanding the value of education. In S. Ibrahim \& M. Tiwari (Eds.), The capability approach: From theory to practice (pp. 206-230). Palgrave Macmillan. 
Childs, E. C. (2005). Looking behind the stereotypes of the "angry black woman" an exploration of Black women's responses to interracial relationships. Gender E Society, 19(4), 544-561.

Cin, F. M., \& Walker, M. (2016). Reconsidering girls' education in Turkey from a capabilities and feminist perspective. International Fournal of Educational Development, 49, 134-143.

Collopy, R. (2003). Curriculum materials as a professional development tool: How a mathematics textbook affected two teachers' learning. The Elementary School fournal, 103(3), 287-311.

Cundiff, J. L., Vescio, T. K., Loken, E., \& Lo, L. (2013). Do gender-science stereotypes predict science identification and science career aspirations among undergraduate science majors? Social Psychology of Education, 16(4), 541-554.

Dasgupta, N., \& Stout, J. G. (2014). Girls and women in science, technology, engineering, and mathematics: STEMing the tide and broadening participation in STEM careers. Policy Insights from the Behavioral and Brain Sciences, 1(1), 21-29. https:// doi.org/10.1177/237273221454947 1

DeJaeghere, J. (2018). Girls' educational aspirations and agency: Imagining alternative futures through schooling in a low-resourced Tanzanian community. Critical Studies in Education, 59(2), 237-255.

Drake, C., Spillane, J. P., \& Hufferd-Ackles, K. (2001). Storied identities: Teacher learning and subject-matter context. Fournal of Curriculum Studies, 33(1), 1-23.

Education Bureau. (2014). Guide on life planning education and career guidance for secondary schools (1st ed.). https://careerguidance.edb.hkedcity.net/edb/export/sites/default/ lifeplanning/.pdf/about-careers-guidance/CLP-Guide_E_r3.pdf

Education Bureau. (2016). Report on promotion of STEM education: Unleashing potential in innovation. Hong Kong Education Bureau.

El Nagdi, M., \& Roehrig, G. (2020). Identity evolution of STEM teachers in Egyptian STEM schools in a time of transition: A case study. International Fournal of STEM Education, 7(41). https://doi.org/10.1186/s40594-020-00235-2

El Nagdi, M., Leammukda, F., \& Roehrig, G. (2018). Developing identities of STEM teachers at emerging STEM schools. International fournal of STEM Education, 5(36), 1-13. https://doi.org/10.1186/s40594-018-0136-1

European Institute for Gender Equality. (2017). Economic benefits of gender equality in the EU: How gender equality in STEM education leads to economic growth. https://eige.europa.eu/sites/ default/files/documents/2017.2082_mh0217177enn_pdfweb_20170803123353.pdf

Franzosa, S. D. (1992). Authoring the educated self: Educational autobiography and resistance. Educational Theory, 42(4).

Gibbs, G. R. (2007). Thematic coding and categorizing: Analyzing qualitative data. Sage.

Gokpinar, T, \& Reiss, M. (2016). The role of outside-school factors in science education: A two-stage theoretical model linking Bourdieu and Sen, with a case study. International Fournal of Science Education, 38(8), 1278-1303.

Grace, K., \& Eng, S. (2020). A capabilities approach to female graduates' post-secondary academic and career-related goal pursuit in Siem Reap Cambodia. Educational Research for Policy and Practice, 19, 281-299.

Gunn, A., Bennett, S., Evans, L. S., Peterson, B. J., \& Welsh, J. L. (2013). Autobiographies in preservice teacher education: A snapshot tool for building a culturally responsive pedagogy. International Journal of Multicultural Education, 15(1), 1-20. 
Horvath, M., Goodell, J. E., \& Kosteas, V. D. (2018). Decisions to enter and continue in the teaching profession: Evidence from a sample of US secondary STEM teacher candidates. Teaching and Teacher Education, 71, 57-65.

Huang, J., Wang, Y., and Teng, F. (2019). Understanding changes in teacher beliefs and identity formation: A case study of three novice teachers in Hong Kong. Teaching Education. https://doi.org/10.1080/10476210.2019.1693535

Kaleva, S., Pursiainen, J., Hakola, M.et al. (2019). Students' reasons for STEM choices and the relationship of mathematics choice to university admission. International Fournal of STEM Education, 6(43). https://stemeducationjournal.springeropen.com/a rticles/10.1186/s40594-019-0196-x

Kameshwara, K. K., and Shukla, T. (2017). Towards social justice in institutions of higher learning: Addressing gender inequality in Science \& Technology through capability approach. Administrative Science, 7(3), 22-35.

Kutnick, P., Chan, R. Y. Y., \& Chan, C. K. Y.et al. (2018). Aspiring to become an engineer in Hong Kong: Effects of engineering education and demographic background on secondary students' expectation to become an engineer, European Fournal of Engineering Education, 43(6), $824-841$.

Kutnick, P., Lee, B. P. K., Chan, R. Y. Y., \& Chan, C. (2020). Students' engineering experience and aspirations within STEM education in Hong Kong secondary schools. International Fournal of Educational Research, 103, 101610.

Lam, J. (2018, October 19). STEM education for all: Girls Go Tech Programme empowers HK female secondary students to pursue tech subjects. SCMP. https://www. scmp.com/yp/discover/lifestyle/features/article/3057512/stem-education-all-girls-gotech-programme-empowers

Lee, J. F. (2014). Gender representation in Hong Kong primary school ELT textbooks - a comparative study. Gender and Education, 26(4), 356-376.

Legislative Council Secretariat. (2020). Nurturing of local talent. Research Brief Issue 3. https:// www.legco.gov.hk/research-publications/english/1920rb03-nurturing-of-local-talent-20 200601-e.pdf

Lo, W. Y. W., \& Tang, H. H. H. (2020). Chasing phantoms? Innovation policy, higher education and the pursuit of a knowledge economy in Hong Kong. Fournal of Higher Education Policy and Management, 42(2), 178-193.

Luttrell, W. (2010). Introduction: The promise of qualitative research in education. In W. Luttrell (Ed.), Qualitative educational research: Readings in reflexive methodology and transformative practice (pp. 1-17). Routledge.

Makarova, E, Aeschlimann, B., \& Herzog, W. (2019). The gender gap in STEM fields: The impact of the gender stereotype of math and science on secondary students' career aspirations. Front. Education, 4(60). https://doi.org/10.3389/ feduc. 2019.00060

Margot, K. C., \& Kettler, T. (2019). Teachers' perception of STEM integration and education: A systematic literature review. International foumal of STEM Education, 6(2). https://stemeducationjournal.springeropen.com/articles/10.1186/s40594-018-0151-2 \#citeas

Mascret, N., \& Cury, F. (2015). "I'm not scientifically gifted, I'ma girl”: Implicit measures of gender-science stereotypes-preliminary evidence. Educational Studies, 41(4), 462-465.

Medina, Y. (2016). In the name of teaching: The embodied journey of a different kind of educator. Educational Studies, 52(2), 177-187. 
Mezirow, J. (1997). Transformative learning: Theory to practice. New Directions for Adult and Continuing Education, 74, 5-12.

Molyneux, M., \& Razavi, S. (Eds.). (2002). Gender justice, development, and rights. Oxford University Press.

Mullis, I. V. S., Martin, M. O., and Loveless, T. (2016). 20 years of TIMSS: International trends in mathematics and science achievement, curriculum, and instruction. TIMSS and PIRL International Study Center.

OECD. (2016). PISA 2015 results (Vol. 1): Excellence and equity in education. OECD Publishing.

OECD. (2019). PISA 2018 results (Vol. 1): What students know and can do. OECD Publishing. https://www.oecd.org/education/pisa-2018-results-volume-i-5f07c754-en.htm

Powell, R. R., Zehm, S. J., \& Garcia, J. (1996). Field experience: Strategies for exploring diversity in schools. Prentice Hall.

Robeyns, I. (2003). Sen's Capability Approach and gender inequality: Selecting relevant capabilities. Feminist Economics, 9(2-3), 61-92.

Robeyns, I. (2017). Wellbeing, freedom and social justice: The capability approach re-examined. Open Book Publishers.

Sachs, J. (2001). Teacher professional identity: Competing discourses, competing outcomes. Fournal of Education Policy, 16(2), 149-161. https://doi.org/10.1080/ 02680930116819

Sanders, M. (2009). STEM, STEM education STEM mania. The Technology Teacher, 68(4), 20-26.

Schuster C, \& Martiny S. E. (2017). Not feeling good in STEM: Effects of stereotype activation and anticipated affect on women's career aspirations. Sex Roles, 76(1), 40-55. https://doi.org/10.1007/s11199-016-0665-3

Sen, A. (1999). Development as freedom. Oxford University Press.

Seyranian, V., Madva, A., Duong, N.et al. (2018). The longitudinal effects of STEM identity and gender on flourishing and achievement in college physics. International Fournal of STEM Education, 5(40). https://stemeducationjournal.springeropen.com/a rticles/10.1186/s40594-018-0137-0

Shapiro, J. R. (2011). Different groups, different threats: A multi-threat approach to the experience of stereotype threats. Personality and Social Psychology Bulletin, 37, 464480. https://doi.org/10.1177/0146167211398140

Shapiro, J. R., \& Neuberg, S. L. (2007). From stereotype threat to stereotype threats: Implications of a multi-threat framework for causes, moderators, mediators, consequences, and interventions. Personality and Social Psychology Review, 11, 107-130. https: doi.org/10.1177/1088868306294790

Shapiro, J. R., \& Williams, A. M. (2012). The role of stereotype threats in undermining girls' and women's performance and interest in STEM fields. Sex Roles: A Fournal of Research, 66(3-4), 175-183.

Sharif, N., \& Tang, H. H. H. (2014). New trends in innovation strategy at Chinese universities in Hong Kong and Shenzhen. International fournal of Technology Management, 65(1), 300-318.

Simon, R. A., Aulls, M. W., Dedic, H., Hubbard, K. A., \& Hall, N. G. (2015). Exploring student persistence in STEM programs: A motivational model. Canadian Fournal of Education, 38(1), 1-27.

Simpson, A., \& Bouhafa, Y. (2020). Youths' and adults' identity in STEM: A systematic literature review. Fournal for STEM Education Research, 3, 167-194. 
Slavit, D., Nelson, T., \& Lesseig, K. (2016). The teachers' role in developing, opening, and nurturing an inclusive STEM-focused school. International fournal of STEM Education, 3 (7), 1-17. https://doi.org/10.1186/s40594-016-0040-5

So, W. W. M., \& Chiu, S. W. K. (2020). Challenges and opportunities with Hong Kong students' science, technology, engineering and mathematics aspirations. Policy Innovation and Co-ordination Office of the Government of the Hong Kong Special Administrative Region.

Spencer, S. J., Logel, G., \& Davies, P. G. (2016). Stereotype threat. Annual Review of Psychology, 67(1), 415-437.

Steele, C. M. (1997). A threat in the air: How stereotypes shape intellectual identity and performance. American Psychologist, 52(6), 613-629.

Stoet, G., \& Geary, D. C. (2018). The gender-equality paradox in science, technology, engineering, and mathematics education. Psychological Science, 29(4), 581-593. https:// doi.org/10.1177/0956797617741719

Talafian, H., Moy, M. K., Woodard, M. A.et al. (2019). STEM identity exploration through an immersive learning environment. Fournal for STEM Education Research, 2, 105-127.

Tang, H. H. H. (2020). The strategic role of world class universities and academic profession in regional innovation system: The case of China's Greater Bay Area. Asian Education and Development Studies.https://www.emerald.com/insight/content/ doi/10.1108/AEDS-10-2019-0163/full/html

Tang, H. H. H., \& Chau, C. F. W. (2020). Knowledge exchange in a global city: A typology of universities and institutional analysis. European Fournal of Higher Education, $10(1), 93-112$.

The Academy of Sciences of Hong Kong. (2017). Science, technology and mathematics education in the development of the innovation and technology ecosystem of Hong Kong. The Academy of Sciences of Hong Kong.

The Women's Foundation. (2015). Girls Go Tech. https://www.ggthk.org/stem_ hub/about.jsp

Trent, J. (2010). Teacher education as identity construction: Insights from action research. Foumal of Education for Teaching: International Research and Pedagogy, 36(2), 153-168. https:// doi.org/10.1080/02607471003651672

Ukpokodu, O. N. (2003). Teaching multicultural education from a critical perspective: Challenges and dilemmas. Multicultural Perspectives: An Official Fournal of the National Association for Multicultural Education, 5(4), 17-23.

Unterhalter, E. (2007). Gender, schooling and global social justice. Routledge.

Walker, M. and Loots, S. (2018). Transformative change in higher education through participatory action research: A capabilities analysis. Educational Action Research, 26(1), 166-181.

Walther, J., Sochacka, N. W., \& Kellam, N. N. (2013). Quality in interpretive engineering education research: Reflections on an example study. Fournal of Engineering Education, 102(4), 626-659. http://dx.doi.org/10.1002/jee.20029

Wenger, E. (1998). Communities of practice: Learning, meaning and identity. Cambridge University Press.

Wenger, E., McDermott, R., \& Snyder, W. (2002). Cultivating communities of practice: A guide to managing knowledge. Harvard Business School Press.

Women's Commission. (2019). Hong Kong women in figures 2019. Hong Kong Women's Commission.

Yau, H. K., Kan, M. S., \& Cheng Alison, L. F. (2012). The impact of curiosity and external regulation on intrinsic motivation: An empirical study in Hong Kong education. Psychology Research, 2(5), 295-307. 


\section{Hei-hang Hayes Tang et al.}

Yeung, D. and Liong, M. (2016). To STEM or not to STEM? Factors influencing adolescent girls' choice of STEM subjects [Final Report]. Hong Kong Women's Foundation.

Yuen, G. Y. (2015). Gender differences in life satisfaction and spiritual health among the junior immigrant and local Hong Kong secondary students. International Fournal of Children's Spirituality, 20(2), 139-154. 